\title{
Fluoroquinolones Protect the Human Lymphocyte CEM Cell Line from HIV-1-Mediated Cytotoxicity
}

\author{
Junko Nozaki-Renard ${ }^{1}$, Takashi Jino ${ }^{2}$, Yoshinari Sato ${ }^{2}$, Yasumasa Marumoto ${ }^{2}$, Genkichi Ohta $^{2}$ and \\ Mitsuru Furusawa ${ }^{2 \dagger}$ \\ 'Department of Microbiology, Tokyo Medical College, Shinjuku 6-chome, Shinjuku-ku, Tokyo 160 and \\ ${ }^{2}$ Molecular Biology Research Laboratory, Research Institute, Daiichi Pharmaceutical Co., Ltd., 16-13, \\ Kitakasai 1-chome, Edogawa-ku, Tokyo 134, Japan
}

Key words: AIDS/HIV-1/cytopathic effect/fluoroquinolone

\begin{abstract}
$A B S T R A C T$. Infection of the human lymphocyte CEM cell line with the HIV-1 (human immunodeficiency virus type-1, LAV-1 strain) results in cell death. A fluoroquinolone antibiotic, ofloxacin, protected the infected cells from HIV-1-mediated cytolysis. Other fluoroquinolones, e.g. ciprofloxacin, norfloxacin, and enoxacin, also protected the infected cells from HIV-1-mediated cytolysis. The d-isomer of ofloxacin (DR-3354) was about 50fold less effective than the l-isomer (DR-3355). Almost none of the rescued cells had detectable HIV-antigens and they could be maintained for long periods in vitro without drugs.
\end{abstract}

The new fluoroquinolones, such as ofloxacin (17), ciprofloxacin (24), and norfloxacin (10), are chemical compounds derived from nalidixic acid and possess potent antibacterial activity (14). They have been used clinically for a variety of infectious diseases due to their broad spectrum of target bacteria and relatively weak side effects (9). Although there have been several reports describing inhibitory activity of quinolone related compounds against reverse transcriptase of murine and avian retroviruses (20) and HIV-1 (Fifth Int. Conf. AIDS Abstract: \# C624), no studies have been reported for HIV-1-mediated cytotoxicity. These viruses have gained particular importance recently due to the finding that HIV-1 mediates the onset of the acquired immunodeficiency syndrome (AIDS) $(1,13)$.

AIDS is characterized by a progressive depletion of the helper T-lymphocyte subset $(11,25)$. HIV-1 infection of susceptible human lymphocyte cell lines and subsequent cell destruction constitute a valid in vitro model system for the action of HIV in generating AIDS. HIV1 infection of these cell lines inevitably leads to cell death and thus they provide a useful screening system for potential anti-AIDS drugs (6). In this report, we demonstrate that several fluoroquinolones protect cells from HIV-mediated cytotoxicity.

\section{MATERIALS AND METHODS}

Infection and culture of cells. CEM cells (16) were used to

\footnotetext{
$\dagger$ To whom correspondence should be addressed.
}

test the action of the various fluoroquinolones on HIV-1 (LAV-1 strain, a gift from Dr. L. Montagnier) infected cells. Cell-free supernatants from virus-infected CEM cells were used as the virus source. The supernatants contained approximately $5 \times 10^{6} \mathrm{TCID} 50 / \mathrm{ml}$ (TCID50 $=50 \%$ tissue culture infectious dose) and were stored at $-70^{\circ} \mathrm{C}$ before use.

CEM cells were cultured in RPMI 1640 supplemented with $10 \% \mathrm{FCS}$ in humidified $5 \% \mathrm{CO}_{2} /$ air at $37^{\circ} \mathrm{C}$. The cells were infected with HIV-1 on day 0 by adding the stock viral solution to the host cells at MOI (multiplicity of infection) $=0.05$ and incubating at $37^{\circ} \mathrm{C}$ for $90 \mathrm{~min}$ with stirring at $30 \mathrm{~min}$ intervals. Fresh culture medium was added to the infected cells for a cell density of $2.5 \times 10^{5}$ cells $/ \mathrm{ml}$ to give the HIV-infected cell suspension, and $2 \mathrm{ml}$ of the cell suspension was added to each well of 24 -well culture plates $\left(2.5 \times 10^{5}\right.$ cells $\left./ \mathrm{ml}\right)$. Under these experimental conditions, HIV-1-infected cells died within about 3 weeks; however, in some experiments a few cells were rescued spontaneously without any drug. This phenomenon has been already reported by Folks et al. (3).

Fluoroquinolone treatment. Drugs were dissolved in physiological saline and added to the cell medium after the viral infection on day 0 at the final concentrations indicated in Figure 1 and Table I. The culture medium was changed on days 4,10 , 15,20 , and 25 by agitating the cultures with a pipette to suspend the cells and adding $0.5 \mathrm{ml}$ of cell suspension to $2 \mathrm{ml}$ of fresh medium without drug. Thus, the fluoroquinolones were initially present at the indicated concentrations for only 4 days post-infection and the compounds were progressively diluted by $1: 5$ with each medium change. On days $4,7,10,20$, and 30 , the number of viable cells, viability, and number of HIV antigen-positive cells were determined. Cell viability was 
determined by trypan blue exclusion.

Immunofluorescence for $H I V-I$ antigens. The presence of HIV antigen in infected cells was determined by indirect immunofluorescence microscopy using serum from an HIV-1-infected asymptomatic carrier. Cells were mounted on a slide, fixed with acetone for $10 \mathrm{~min}$ at $-20^{\circ} \mathrm{C}$, incubated with 150 fold diluted carrier serum, and stained with 50-fold diluted FITC-conjugated goat anti-human IgG $\mathrm{F}\left(a b^{\prime}\right)_{2}$ fragments (Cappel).

\section{RESULTS}

Infection of CEM cells with HIV-1 led to essentially a complete loss of cell viability within 30 days, and by day 4 about $80 \%$ of the cell were positive for HIV antigen (Fig. 1, Table I). In contrast, incubation with ofloxacin protected a significant subpopulation of cells from HIV-mediated cytotoxicity (Fig. 1). The rate of appearance of the surviving cells was dose-dependent between 1 and $10 \mu \mathrm{g} / \mathrm{ml}$ (Fig. 1a), and $5 \mu \mathrm{g} / \mathrm{ml}$ ofloxacin was sufficient for $90 \%$ viability by day 10 (Fig. 1b). Maintenance of cell viability was paralleled by a gradual loss of $\mathrm{HIV}$ antigen-positive cells to less than $1 \%$ at day 30 (Fig. 1c).

Incubation of the HIV-infected cells with a variety of other fluoroquinolones resulted in surviving cell populations in a manner similar to that observed with ofloxacin (Table I). The rate of appearance of the surviving cells was dose-dependent for each fluoroquinolone tested, and $10 \mu \mathrm{g} / \mathrm{ml}$ drug was sufficient for more than $90 \%$ viability by day 30 . Other than ofloxacin, the most effective compounds were ciprofloxacin, DR-3355 (1isomer of ofloxacin), and the Ia derivative of ofloxacin (7), all of which have comparable antibacterial activity $(7,14,23)$. The d-isomer of ofloxacin (DR-3354) was about 50-fold less effective than the l-isomer (DR-3355), which reflects similar differences in their antibacterial activity (8). Despite comparable antibacterial activity (unpublished data), the n-propyl derivative of ofloxacin (Ia) was more effective than the 4-acetoyl derivative (Ib). This may be related to their relative degrees of hydrophobicity and the consequently greater ability of the n-propyl compound to penetrate the cell membrane. The quinolone analogue, enoxacin (2), also had cellprotecting activity.

The optimal concentration of ofloxacin and DR-3355 for protection of the infected cells had no effect on cell viability of uninfected control cells when cultured continuously with either drug for up to 32 days (data not shown). However, toxicity was observed after continuous culture with $50 \mu \mathrm{g} / \mathrm{ml} \mathrm{DR}-3355(5 \times$ optimal concentration) as judged by a decrease in the cell growth rate (data not shown).

Pre-treatment of CEM cells with DR-3355 followed by HIV exposure did not protect the cells from HIV- a

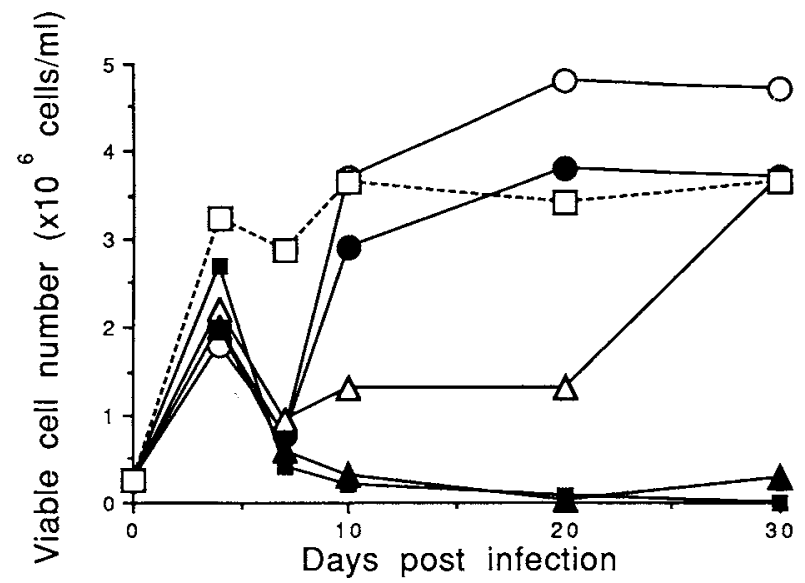

b

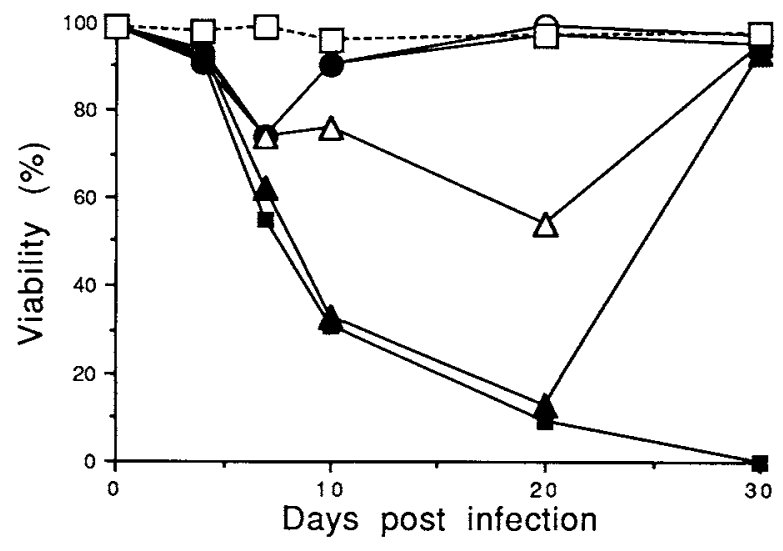

c

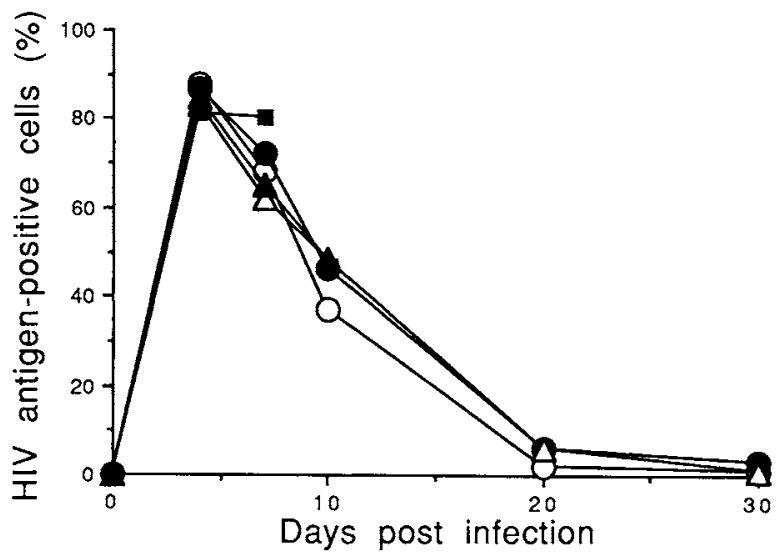

Fig. 1. Ofloxacin rescues HIV-1-infected CEM cells. CEM cells were infected with HIV-1 on day 0 and incubated at $37^{\circ} \mathrm{C}$ from day $0-4$ with final concentrations of ofloxacin of $1 \mu \mathrm{g} / \mathrm{ml}(\Delta), 2.5 \mu \mathrm{g} / \mathrm{ml}(\Delta)$, $5 \mu \mathrm{g} / \mathrm{ml}(\bullet)$, or $10 \mu \mathrm{g} / \mathrm{ml}(\bigcirc)$. Control cells included infected cells incubated with saline ( $\mathbf{m}$ ) and non-infected cells $(\square)$. Drug concentrations were diluted 5-fold at each medium change on days $4,10,15,20$, and 25 . On the days indicated, cells were tested for viable cell number (a), percent viability (b), and percent HIV antigen-positive cells (c) as described in Materials and Methods. 


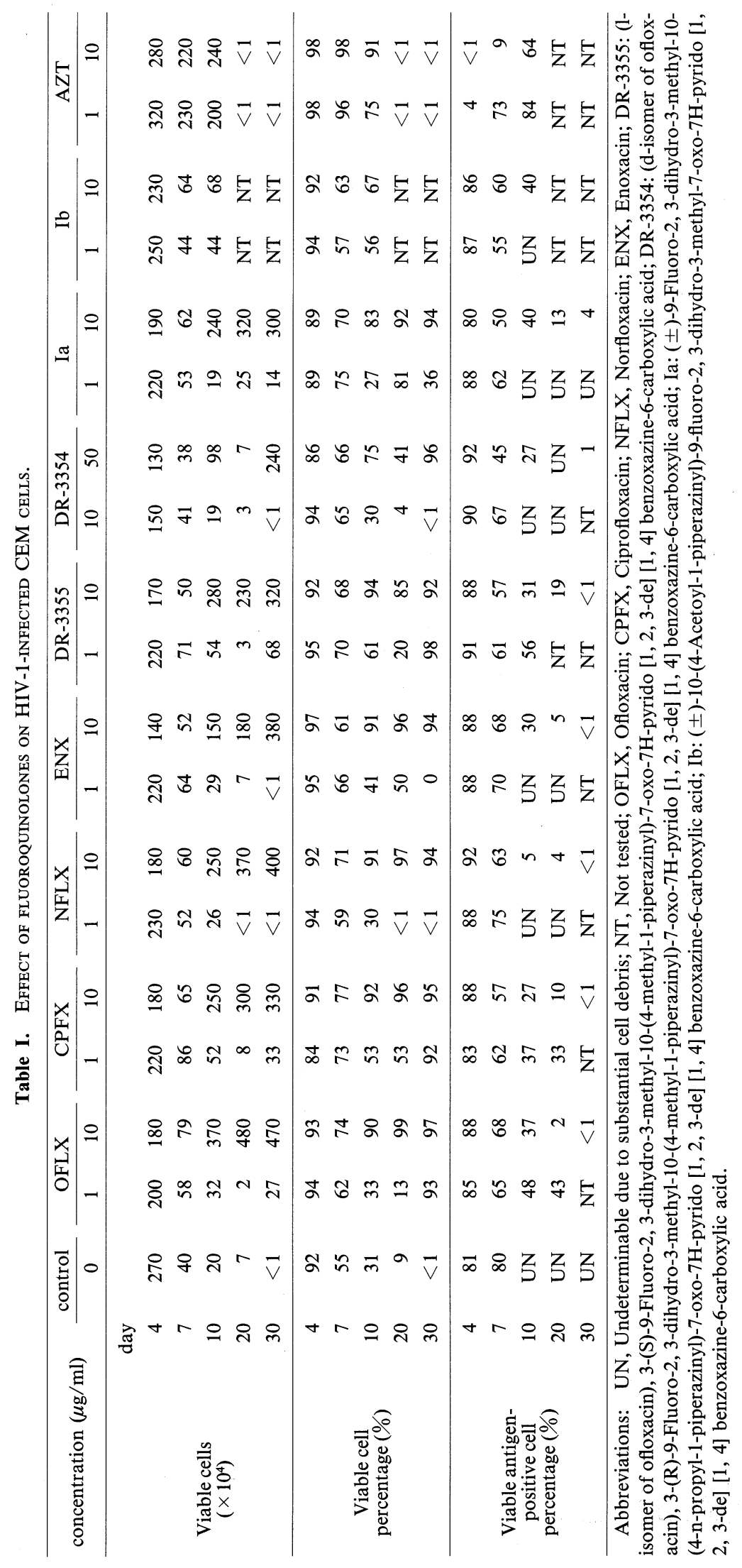


induced cytotoxicity. Novobiocin, which is a nonquinolone antibacterial drug, showed weak cell-protecting activity at $100 \mu \mathrm{g} / \mathrm{ml}$, and nalidixic acid had no antiviral effect (data not shown). In control experiments, 3 'azido-3'-deoxythymidine (AZT) dramatically protected CEM cells from HIV-1 cytotoxicity up to day 10 by inhibiting viral propagation $(4,15)$, but eventually all the cells were killed by the infection by day 20 without additional AZT (Table I).

Interestingly, the surviving CEM cell populations had very few HIV antigen-positive cells as shown in Table I and Figure 1c. Related to this is the observation that protected cells arising from the initial 4-day treatment with ofloxacin or DR-3355 have been maintained in culture for at least 3 months so far in the absence of drugs with no loss in cell viability. Essentially the same results were obtained with HUT-78 and MT-4 cells, except that the surviving populations had a higher percentage of cells with HIV antigen and HUT-78 cells required continuous culture with DR-3355 for survival (data not shown).

\section{DISCUSSION}

While the mechanism of HIV-induced cytotoxicity is unresolved $(18,19,21)$, the notion that the fluoroquinolones interrupt a critical viral function is supported by the finding that drug treatment of infected cells, but not pre-treatment of control cells, results in protection from HIV-mediated cytotoxicity. The antibacterial activity of the fluoroquinolones is reportedly related to effects on bacterial gyrase $(5,22)$, and similar effects on functionally related HIV-1 proteins (e.g. integrase) can be hypothesized as a possible mode of action resulting in cell survival. Recently, tetracycline derivatives were reported to protect HIV-1-infected cells against cytolysis. The drug target was speculated to be mycoplasma (12), although there was neither evidence presented for the presence of mycoplasma nor for mycoplasma involvement in the cytopathology characteristic of HIV-1 infected cells. Regardless of the mechanism, it is clear that fluoroquinolone treatment of HIV-1 infected CEM cells rescues cells from the otherwise lethal infection and permits cell proliferation in long-term cultures.

This in vitro evidence suggests that selected fluoroquinolones might be considered in clinical trials as possible AIDS drugs. However, it is always difficult to predict potential in vivo clinical effects solely on the basis of in vitro data. While these drugs have been proven clinically safe (9), they were evaluated primarily for antibiotic activity. The current data suggest that AIDS patients being treated with fluoroquinolones as antibacterial agents should be followed not only for inhibition of opportunistic infections, but also carefully observed from the viewpoint of improvement of immune deficiency.

Acknowledgements. We would like to thank Dr. W. Ostertag for illuminating scientific discussions, Dr. D. Stearns-Kurosawa for reading the manuscript and useful suggestions, and Dr. I. Hayakawa for quinolone compounds and discussions.

\section{REFERENCES}

1. Barre-Sinoussi, F., Chermann, J.C., Rey, F., Nugeyre, M.T., Chamaret, S., Gruest, J., Dauguet, C., Axler-Blin, C., Vezinet-Brun, F., Rouzioux, C., Rozenbaum, W., and Montagnier, L. (1983). Isolation of a T-lymphotropic retrovirus from a patient at risk for acquired immune deficiency syndrome (AIDS). Science 220: 868-871.

2. Chartrand, S.A., Scribner, R.K., Weber, A.H., and Weich, D.F. (1983). In vitro activity of CI-919 (AT-2266), an oral antipseudomonal compound. Antimicrob. Agents Chemother. 23: 658-663.

3. Folks, T., Powell, D.M., Lightroote, M.M., Benn, S., MARTIN, M.A., and FAUCI, A.S. (1986). Induction of HTLVIII/LAV from a nonvirus-producing T-cell line: Implication for latency. Science 231: 600-602.

4. Furman, P.A., Fyfe, J.A., St. Clatr, M.H., Weinhold, K., Rideout, J.L., Freeman, G.A., Lehrman, S.N., Bolognese, D.P., Broder, S., Mitsuya, H., and Barry, D.W. (1986). Phosphorylation of $3^{\prime}$-azido-3'-deoxythymidine and selective interaction of the $5^{\prime}$-triphosphate with human immunodeficiency virus transcriptase. Proc. Natl. Acad. Sci. USA 83: 8333-8337.

5. Gellert, M., Mizuuchi, K., O’Dea, M.H., Itoh, T., and TomizawA, J. (1977). Nalidixic acid resistance: A second genetic character involved in DNA gyrase activity. Proc. Natl. Acad. Sci. USA 74: 4772-4776.

6. Harada, S., Koyanagi, Y. and Yamamoto, N. (1985). Infection of HTLV-III/LAV in HTLV-I-carrying cells MT-2 and MT-4 and application in a plaque assay. Science 229: 563-566.

7. Hayakawa, I., Hiramitsu, T., and Tanaka, Y. (1984). Synthesis and antibacterial activities of substituted 7-0xo-2, 3dihydro-7H-pyrido [1, 2, 3-de] [1, 4] benzoxazine-6-carboxylic acids. Chem. Pharm. Bull. 32: 4907-4913.

8. Hayakawa, I., Atarashi, S., Yokohama, S., Imamura, M., SaKano, K., and Furukawa, M. (1986). Synthesis and antibacterial activities of optically active ofloxacin. Antimicrob. Agents Chemother, 29: 163-164.

9. HOOPER, D.C. and Wolfson, J.S. (1989). Adverse effects of quinolone antimicrobial agents. In Quinolone Antimicrobial Agents. (J.S. Wolfson and D.C. Hooper, eds.), American Society for Microbiology, Washington, D.C. pp. 249-271.

10. Ito, A., Hirai, K., Inoue, M., Koga, H., Suzue, S., Irikura, T., and Mitsuhashi, S. (1980). In vitro antibacterial activity of AM-715, a new nalidixic acid analog. Antimicrob. Agents Chemother. 17: 103-108.

11. Klatzmann, D., Barre-Sinoussi, F., Mugeyre, M.T., Dauguet, C., Vilmer, E., Griscelli, C., Brun-Vezinet, F., Rouzioux, C., Gluckman, J.C., Chermann, J.C., and Montagnier, L. (1984). Selective tropism of lymphadenopathy associated virus (LAV) for helper-inducer T lymphocytes. Science 225: 59-63.

12. Lemaitre, M., Guetard, D., Hienin, Y., Montagnier, L., and Zertal, A. (1990). Protective activity of tetracycline analogs against the cytopathic effect of the human immunodeficiency 
viruses in CEM cells. Res. Virol, 141: 5-16.

13. Levy, J.A. Hoffman, A.D., Kramer, S.M., Landis, J.A., ShimabukURo, J.M., and Oshiro, L.S. (1984). Isolation of lymphocytopathic retroviruses from San Francisco patients with AIDS. Science 225: 840-842.

14. Mitscher, L.A., Zavod, R.M., Sharma, P.N., Chu, D.T.W., Shen, L.L., and Pernet, A.G. (1988). Recent advances on quinolone antimicrobial agents., In Horizons on Antibiotic Research. (B.D. Davis, T. Ichikawa, K. Maeda, and L. A. Mitscher, eds.), Japan Antibiotics Research Association, Tokyo. pp. 166-193.

15. Mitsuya, H., Weinhold, K.J., Furman, P.A., St. Clair, M.H., Lehrman, S.M., Gallo, R.C., Bolognese, D., Barry, D.W., and Broder, S. (1985). 3'-Azido-3'-deoxythymidine (BW A509U): An antiviral agent that inhibits the infectivity and cytopathic effect of human T-lymphotropic virus type III/lymphadenopathy-associated virus in vitro. Proc. Natl. Acad. Sci. USA 82: 7096-7100.

16. Montagnier, L., Clavel, F., Krust, B., Chamaret, S., Rey, F., BARre-Sinoussi, F., and Chermann, J.C. (1985). Identification and antigenicity of the major envelope glycoprotein of lymphadenopathy-associated virus. Virol. 114: 283-289.

17. Sato, K., Matsuura, Y., Inoue, M., Une, T., Osada, Y., OGaWA, H., and Mitsuhashi, S. (1982). In vitro and in vivo activity of DL-8280, a new oxazine derivative Antimicrob. Agents Chemother, 22: 548-553.

18. Sodroski, J., Goh, W.C., Rosen, C., Campbell, K., and Haseltine, W.A. (1986). Role of the HTLV-III/LAV envelope in syncytium formation and cytopathicity. Nature 322:
$470-474$.

19. Somasundaran, M. and Robinson, H.L. (1988). Unexpectedly high levels of HIV-1 RNA and protein synthesis in a cytocidal infection. Science 242: 1554-1557.

20. Sumiyoshi, Y., Nishikawa, T., Watanabe, T., and Kano, K. (1983). Inhibition of retrovirus RNA-dependent DNA polymerase by novobiocin and nalidixic Acid. J. gen. Virol. 640: 2329-2333.

21. Stevenson, M., Meier, C., Mann, A.M., Chapman, N., and WASIAK, A. (1988). Envelope glycoprotein of HIV induces interference and cytolysis resistance in $\mathrm{CD}^{+}$cells: Mechanism for persistence in AIDS. Cell 53: 483-496.

22. Sugino, A., Peebles, C.L., Kreuzer, K.N., and Cozarelli, N.R. (1977). Mechanism of nalidixic acid: Purification of Escherichia coli nalA gene product and its relationship to DNA gyrase and a novel nicking-closing enzyme. Proc. Natl. Acad. Sci. USA 74: 4767-4771.

23. Une, T., Funmoto, T., Sato, K., and Osada, Y. (1988). In vitro activity of DR-3355, an optically active ofloxacin. Antimicrob. Agents Chemother. 32: 1336-1340.

24. Wise, R., ANDrews, J.M., and Edwards, L.J. (1983). In vitro activity of Bay 09867, a new quinolone derivative, compared with those of other antimicrobial agents. Antimicrob. Agents Chemother. 23: 559-564.

25. Zagury, D., Bernard, J., Leonard, R., Cheynier, R., Feldman, M., Sarin, P.S., and Gallo, R.C. (1986). Longterm culture of HTLV-III-infected T cells: A model of cytopathology of T cell depletion in AIDS. Science 231: 850-853.

(Received for publication, June 21, 1990

and in revised form, July 10, 1990) 